\title{
Bacteriophage Based Biosensors: Trends, Outcomes and Challenges
}

\author{
Zahra Aliakbar Ahovan ${ }^{1}$, Ali Hashemi ${ }^{1}, *\left(\mathbb{0}\right.$, Laura Maria De Plano ${ }^{2}$, \\ Mazaher Gholipourmalekabadi ${ }^{3,4, *}$ and Alexander Seifalian ${ }^{5, *(D)}$
}

1 Department of Microbiology, School of Medicine, Shahid Beheshti University of Medical Sciences, Tehran 1985717443, Iran; zahraahovan@sbmu.ac.ir

2 Department of Chemical, Biological, Pharmaceutical and Environmental Sciences, University of Messina, 98166 Messina, Italy; ldeplano@unime.it

3 Cellular and Molecular Research Centre, Iran University of Medical Sciences, Tehran 1449614535, Iran

4 Department of Tissue Engineering \& Regenerative Medicine, Faculty of Advanced Technologies in Medicine, Iran University of Medical Sciences, Tehran 1449614535, Iran

5 Nanotechnology \& Regenerative Medicine Commercialization Centre (NanoRegMed Ltd.), London BioScience Innovation Centre, London NW1 0NH, UK

* Correspondence: ali.hashemi@sbmu.ac.ir (A.H.); mazaher.gholipour@iums.ac.ir (M.G.); a.seifalian@NanoRegMed.com (A.S.)

Received: 5 February 2020; Accepted: 7 March 2020; Published: 11 March 2020

\begin{abstract}
Foodborne pathogens are one of the main concerns in public health, which can have a serious impact on community health and health care systems. Contamination of foods by bacterial pathogens (such as Staphylococcus aureus, Streptococci, Legionella pneumophila, Escherichia coli, Campylobacter jejuni and Salmonella typhimurium) results in human infection. A typical example is the current issue with Coronavirus, which has the potential for foodborne transmission and ruling out such concerns is often difficult. Although, the possible dissemination of such viruses via the food chain has been raised. Standard bacterial detection methods require several hours or even days to obtain the results, and the delay may result in food poisoning to eventuate. Conventional biochemical and microbiological tests are expensive, complex, time-consuming and not always reliable. Therefore, there are urgent demands to develop simple, cheap, quick, sensitive, specific and reliable tests for the detection of these pathogens in foods. Recent advances in smart materials, nanomaterials and biomolecular modeling have been a quantum leap in the development of biosensors in overcoming the limitations of a conventional standard laboratory assay. This research aimed to critically review bacteriophage-based biosensors, used for the detection of foodborne pathogens, as well as their trends, outcomes and challenges are discussed. The future perspective in the use of simple and cheap biosensors is in the development of lab-on-chips, and its availability in every household to test the quality of their food.
\end{abstract}

Keywords: bacteriophage; biosensors; nanomaterials; foodborne pathogens; bacteria; smart materials; nanotechnology; nanoparticles; coronavirus

\section{Introduction}

Over the last several decades, the prevalence of food poisoning has become a major world health issue. This may be due to the increase in intercontinental transportation of food. Dr. Oliver, at the University of Tennessee, TN, USA, an expert in the foodborne pathogens, has recently reported these problems in detail [1]. The Centers for Disease Control and Prevention (CDC), Atlanta, GA, USA assesses more than 36 million cases of the disease annually, are due to foodborne and waterborne pathogens infections [2]. The most common causes of food poisoning are diarrhea, nausea, vomiting 
and stomach cramps. Food poisoning is dangerous for the elderly, as well as children, patients with chronic health conditions or weakened immune systems [3,4].

\section{Common Foodborne Pathogens}

According to the World Health Organization (WHO, Geneva, Switzerland, 2015, www.who.int), there are many possible causes of food poisoning, including; bacteria, viruses, poison, parasites, and many others. Microorganisms involved in food poisoning are generally present in all kinds of foods, especially in fruits, vegetables, as well as supermarket ready-made foods and takeaways [5]. The main pathogens responsible for serious foodborne disease outbreaks are Listeria monocytogenes, Staphylococcus aureus, Salmonella, Campylobacter, Cryptosporidium and E. coli 0157:H7 [6].

\section{Types of Common Methods Used for the Detection of Pathogens}

Conventional methods for the detection of foodborne pathogens depend on specific biochemical and microbiological tests [7]. These methods are time-consuming depending on the time it takes to pre-enrichment of the microorganisms and then culturing them on selective media. These methods are time-consuming, depending on the time it takes for the pre-enrichment of microorganisms and then culturing them on selective media.

In particular, the major problems of current standard technologies are their enrichment steps and time-consuming up to 7-10 days, resulting in inconvenience in many industrial applications, particularly in food [8]. Moreover, viable bacterial strains in the environment can become non-cultivable (viable-but non-cultivable (VBNC)) leading to an underestimation of pathogen numbers or a failure to isolate a pathogen from a contaminated sample. Successively, mass spectrometry has been proposed to increase the speed and sensitivity of culture methods, but these methods have high a cost and require expertise for analyze and interpretation of the data. On the contrary, biochemical immunoassays, such as ELISA, although simple and rapid, can have low sensitivity for the detection of pathogens.

Several different types of nucleic-acid-based assays have been developed and used as a faster technique to detect foodborne pathogens, for example, amplification (PCR), microarrays and biochips [9]. However, PCR techniques of detection, as well as recent multiplex-PCR and reverse transcriptase PCR (RT-PCR) are inefficient to analyze large sample volume without pre-enrichment and have high costs that renders them difficult for regular use [10]. Figure 1 shows the steps involved in the diagnosis and analysis of food samples, using current standard techniques, and the time it takes to detect the pathogen.

Consequently, recently, many researchers in the multidisciplinary team been working in research and development ( $R$ and $\mathrm{D}$ ) of a biosensor, with the following specification, fast report output, simple, specific and sensitive devices able to in-situ, real-time monitoring, at low cost. There have been a number of emerging biosensors technologies, show potential approaches for in situ analysis of pathogen detection. This research aimed, critically review recent advances in biosensors that use bacteriophages or phage-derived as bio-probes for food pathogen detection. 


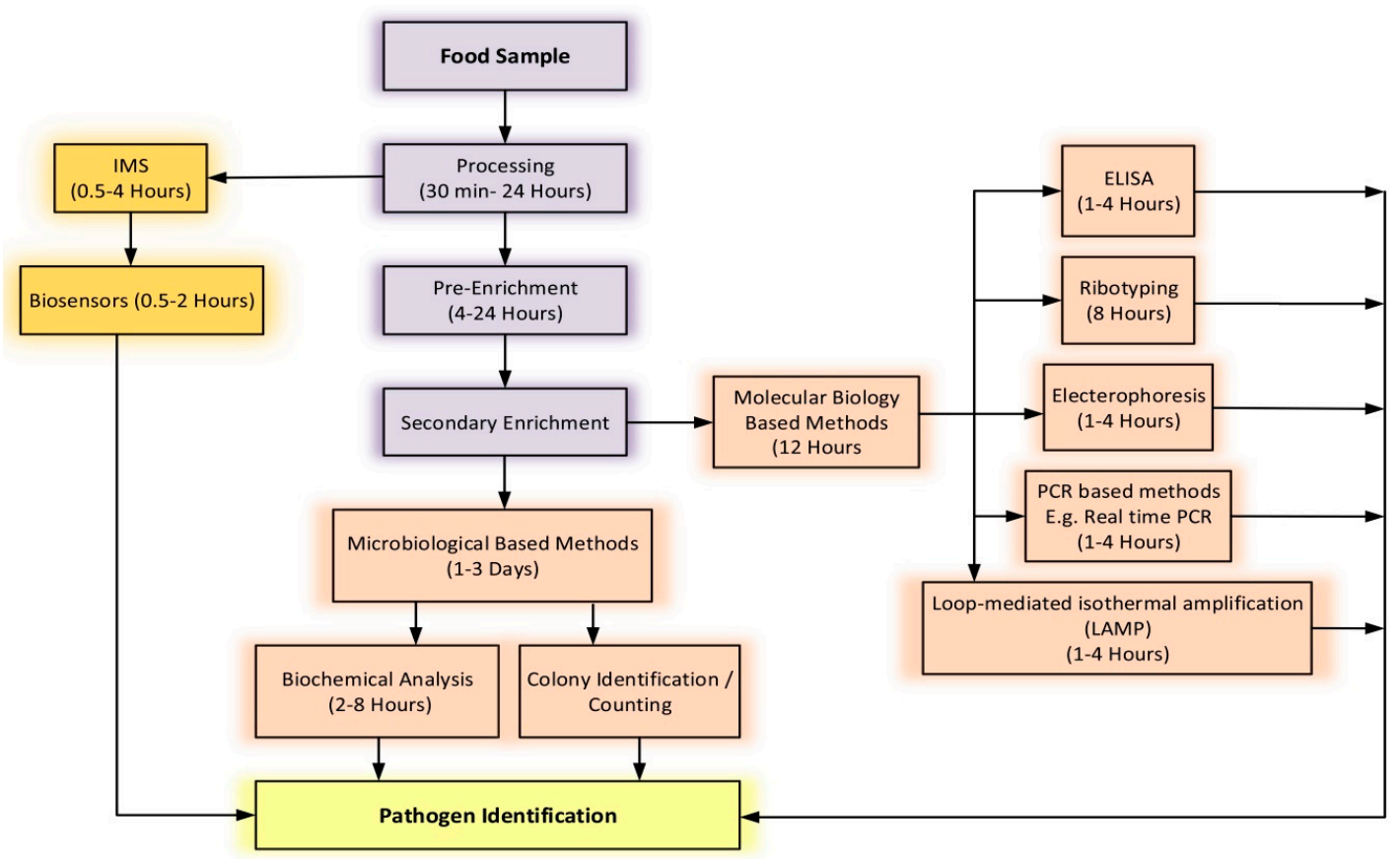

Figure 1. The steps involved in the diagnosis and analysis of food samples using common techniques and the time it takes to detect the pathogen.

\section{Biosensors in Foodborne Pathogen Detection}

The Biosensors are simple and rapid devices, based on organic probes, which are able to identify biological analytes, such as microorganisms, viruses, and biomolecules [11]. The biosensor is commonly composed of a biologically active sensitive element (biological element) and an electronic part (sensor or transducer). The operating principles are as follows: "the biological element" interacts with the substrate to be analyzed and a transduction system; "the sensor" converts the biochemical response into an electrical signal. This signal digitized into a numeric value, giving the final information. Biosensors can be classified according to the transduction technologies used. In the past decade, different groups of transductions have been introduced; these have led to the formation of three main classes: Optical, mass-based and electrochemical transducers (Figure 2) [12]. The front part of the biosensor, the probes, plays a major role in the identification and detection of the pathogens. These give biosensors the ability to analyze a wide range of complex samples in various fields, including the diagnosis of food pathogens, clinical diagnosis and environmental monitoring. Biosensors have been used and played as a useful tool for the direct detection of the pathogen in the factories during the food processed food. Unlike microbiological and molecular methods, biosensors can detect the pathogen immediately and accurately, and this helps to detect the contamination level and the type of food contamination [6].

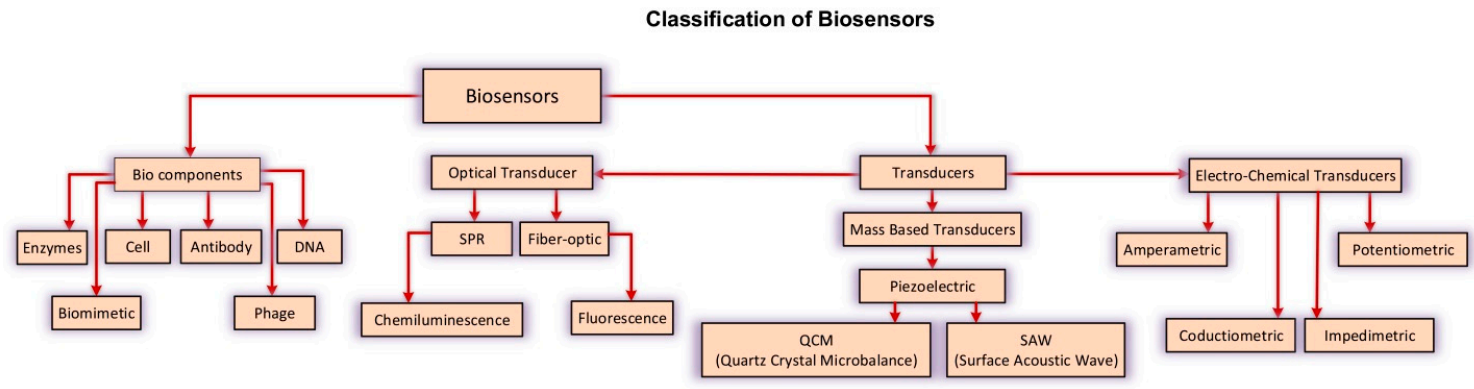

Figure 2. Schematic representation of the components involved in a biosensor devise. 


\section{Bio-Probe}

Bio-probes are the most important components of biosensors because responsible to bind and identify the analytes targets. The two main characteristics of bio-probes are specificity and high affinity for the analyte. Figure 3 shows the different components of a diagnostic sensor. The common bio-probe, used in biosensor devices, are antibodies, proteins, DNA/RNA aptamers and carbohydrates. However, many of these are usually susceptible to environmental conditions and the need for laborious immobilization methods for binding on the sensor substrate. Only recent studies employed bacteriophages (or phage) or derived-phage, such as phage receptor binding proteins (RBPs) and most lately phage-display peptides (PDPs) like a valid alternative of standard bio-probes.

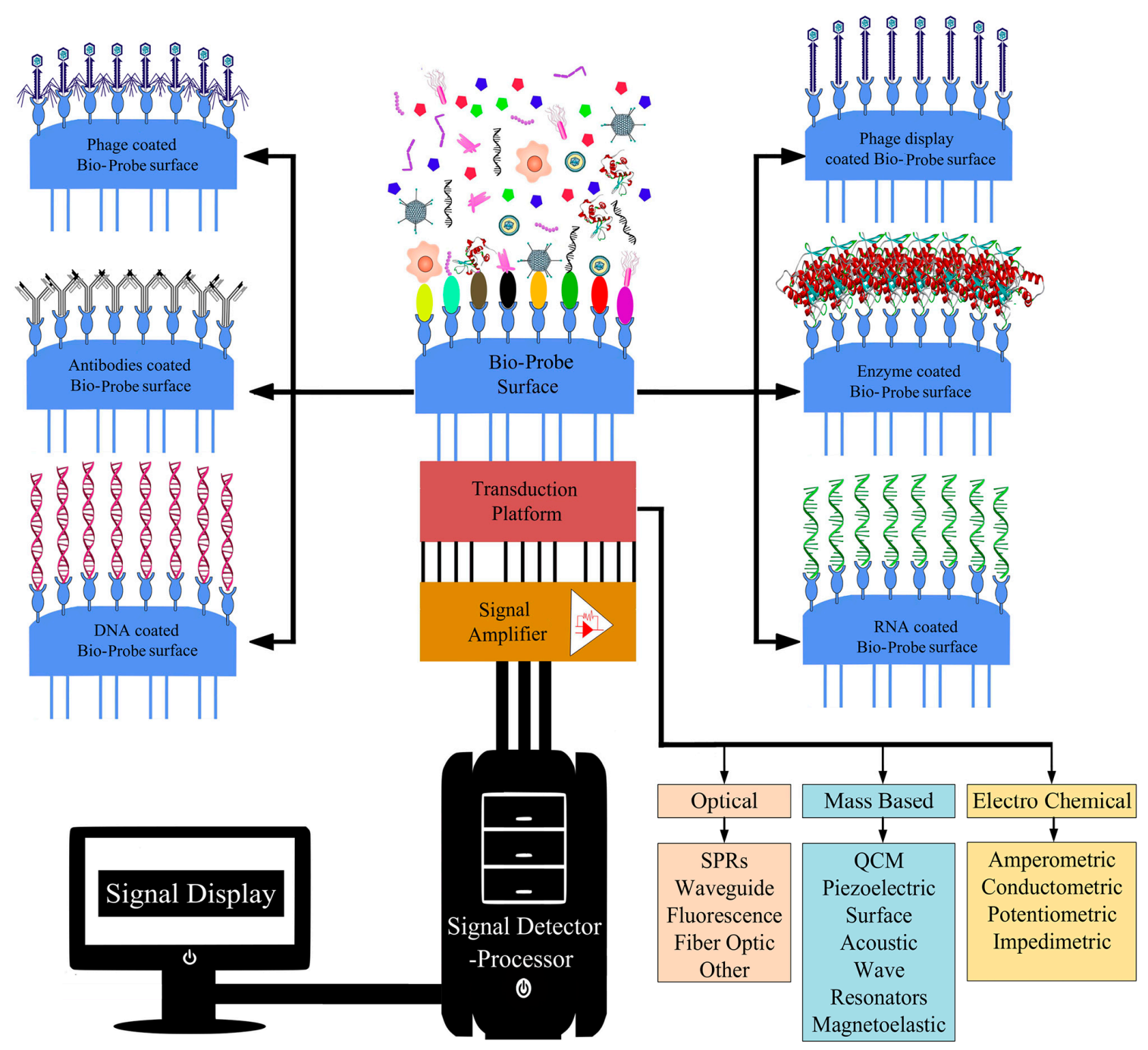

Figure 3. The schematic diagram shows the types of bio-probes and transducer in the biosensor. The figure is shown how the device works to detect pathogens.

\subsection{Phages Wild Type}

Bacteriophages (phages) are viruses ubiquitous in all environments, including soil, food ground and surface water. They specifically bind the host bacteria and inject their DNA to begin the multiplication and propagation of mature virions [13]. Phages can propagate new virions in two ways: Lytic or lysogenic cycle (Figure 4). 
Lysogenic and Lytic Bacteriophage Life Cycle

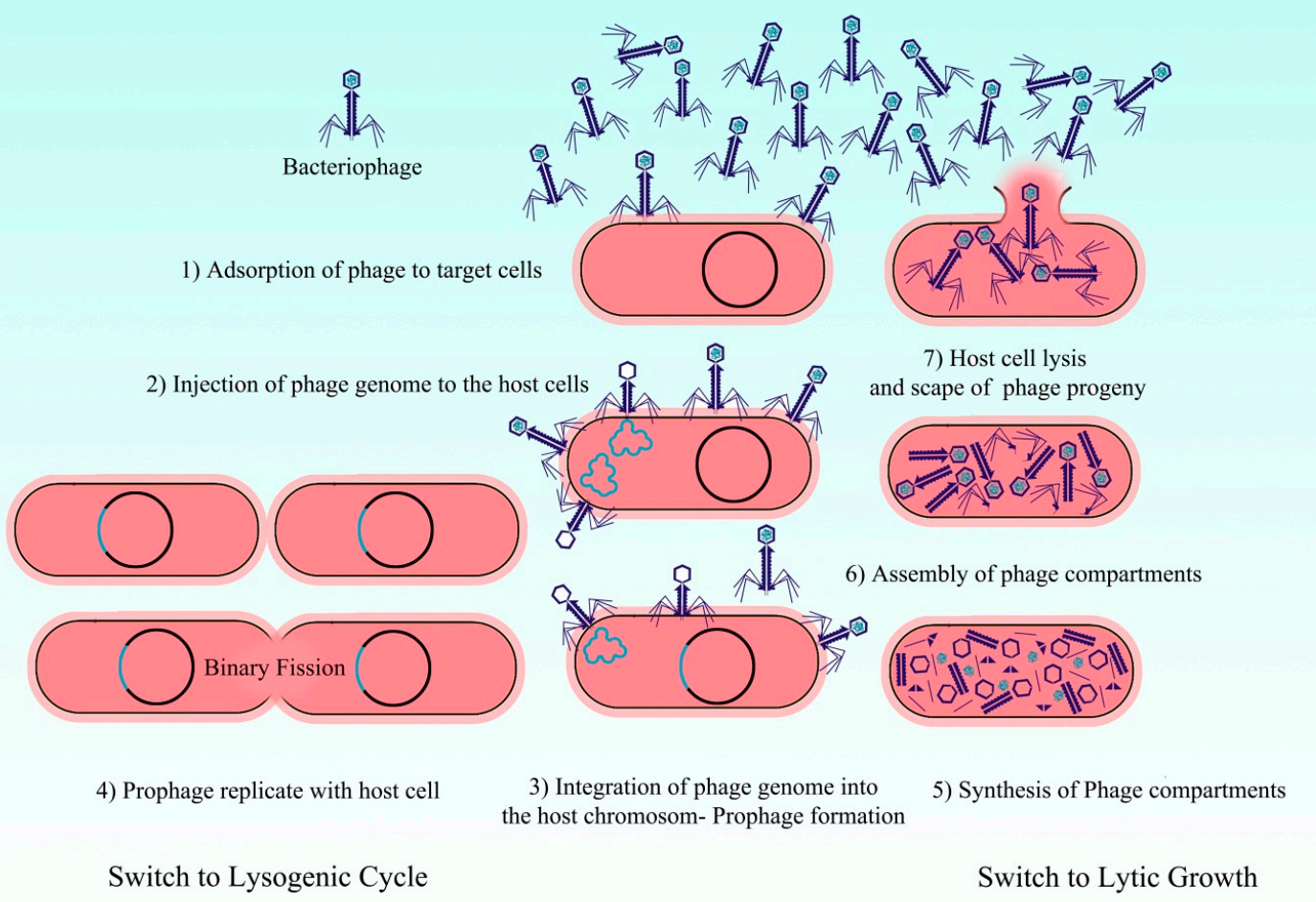

Figure 4. Conversion of lysogenic and lytic state of virulent state in phage-infected bacteria.

Lytic cycle: Phages attach to their host bacteria, insert their DNA and take over the host machinery to dissemination new virions that lyse the bacteria and infect a new host (lytic phages). The host cells provide molecular blocks and enzymes that are needed to multiply the phage genomes and generate a progeny phage. Phages produce several endolysins and holin lysis proteins inside the host cell. Holins are small proteins in the cytoplasmic membrane of host bacteria that lead to peptidoglycan cell wall bacteria lysis by endolysins and release of produced phages. These phages in the external environment can infect and destroy other adjacent bacteria. In a wide range of bacterial species, lytic phage produce infection specifically [14].

Lysogenic cycle: Integrate their genome into the host DNA, remain latent until they arouse for replication and dissemination (lysogenic phage). A Prophage, contained in the host cell, is called lysogen. While, this DNA in the host genome is called a prophage, the lysogenic cycle can continue indefinitely, except in some cases, such as adverse conditions of the environment and bacteria exposure to stress [14].

Consequently, the bacteriophage used like bio-probe in biosensor devises offer several advantages, such as (1) specificity to host bacteria, consequently efficient bacteria screening [15], (2) easy to generate mass quantities of progeny phages, due to their short replication time, (3) ability to tolerate critical conditions, such as organic solvents and large range of $\mathrm{pH}$ and temperature [16]. It is important to understand the characteristics of phages, such as the physical and chemical properties, in order to design the biosensor platform able to bind the phage without losing their ability to recognize the bacteria target. Phages can bind to the gold surface trough van der Waals bonding, hydrophobic bonding and covalent bonding between the gold surface and the amine and thiol groups. This strategy is also used in surface plasmon resonance (SPR) sensor and quartz crystal microbalance (QCM) sensor using phage as a probe for pathogen detection [17]. Nevertheless, optimal condition of physical absorption has 
been found for lytic phages able to detect $S$. aureus by SPR with detection limit $\sim 10^{4} \mathrm{cfu} / \mathrm{mL}^{-1}$, or using magnetic elastic sensors [18] capable of detecting Salmonella (detection limit $10^{3} \mathrm{cfu} / \mathrm{mL}^{-1}$ ) in milk and fat-free [19]. However, physical absorption has several limitations, such as non-specific and weak bonding between phage and sensor surface, leading to desorption during the analytic detection and low surface coverage of deposited phages [17].

However, the chemical bond gives greater stability to the system. One of the main factors in these methods is the creation of a strong chemical bond between the phages and biosensor surfaces, which leads to the development of a stable capture system. In this case, the purity of the suspension of phages, such as their chemical properties, are important to be aware of before performing any chemical reactions [20]. Gervais et al. developed an oriented immobilization of T4 phages using the commonly recognized streptavidin-biotin reaction. The tail-phage was able to detect $E$. coli through the expression of biotin in the T4 head, and using the streptavidin-coated gold surface [21]. Moreover, the T4 phage has been used in the functionalization of magnetic nanobeads, and is used to capture and concentrate E. coli from milk by Mortari et al. The successive lysis of the bacteria-binding phage leads to the analysis of endoplasmic material through impedance, with the potential detection limit of 10 $\mathrm{CFU} / \mathrm{chamber}$ in $30 \mathrm{~min}$ [22].

However, the size of the phage particles can be a limitation in any biosensor surfaces, such as in nanoscale devises. The phages have an enzyme activity relative to their bacterial host [23]. This kind of enzymatic activity on the biosensor surface causes contradictory signals that contribute to the efficiency of the pathogen diagnosis. Moreover, results recommend that whole phage bound on sensor platforms miss their bacterial binding capacity upon drying [24]. As the phages fall on the biosensor surface after upon drying, it likely makes their tail fibers unable to bind to their bacterial host. In order to overcome these limitations, engineered phages or derived phages have been applied in the development of biosensors devises, as discussed later in this review article.

\subsection{Engineered Phages}

With novel advances in the field of genetic engineering, new phage probes have been designed to increase the capability or to overcome the limits of the wild-type phages. Recently, N. Wisuthiphaet and co-workers used engineered bacteriophage, phage T7-ALP, which expresses alkaline phosphatase to detect $E$. coli in beverage samples. After infection of the host bacteria, the overexpression of alkaline phosphatase provides, after the mission of the substrate ELF-97, fluorescence imaging results in high-detection sensitivity of 100 bacteria for gram in $6 \mathrm{~h}$ [25]. In these cases, the specificity of phages, combined with engineered techniques, have permitted the easy and rapid identification of the target.

Reporter Phages - A reporter phage is an engineered phage to produce a signal upon infection of target bacteria. This group of phages detects only live and functional cells because when the phages infect the target bacteria, they activate the cells' machinery to produce a readily detectable signal, which indicates that the target is both present and viable. This technique is an advanced method of bacteria typing [8]. Phage lambda-based cloning vectors bearing a functional bacterial bioluminescence lux operon was used to improve the reporter phage method. Here, lux operon is expressed in the process of infection by phage in the host cell as part of the phage gene [13]. "Lux-" or "Gfp-" expressing phages were successfully used in Salmonella enterica and pathogenic E. coli O157:H7 detection, as well as for detection of Listeria and Mycobacteria [26]. In a study by Zhang et al., the design of a phage that contains luciferase NanoLuc (Nluc), reporter phage, was able to detect E. coli 0157:H7, about 5

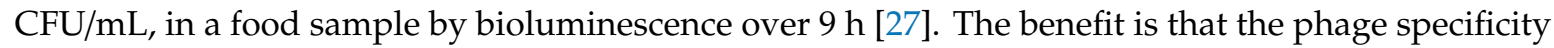
and the strength of the analysis of the phage remove the essential for purification or lengthy sample preparation [28]. Moreover, recently has been shown a proof-of-concept drinking water diagnostic assay for low-cost, rapid and sensitive detection of E. coli using T7 reporter phage. T7 was engineered to express the luceriferase, NanoLuc (NLuc), after the fusion of crystalline cellulose. This novel chimeric reporter allow the detection of $<10 \mathrm{CFU} \mathrm{mL} \mathrm{mL}^{-1}$ E. coli in $3 \mathrm{~h}$ from $100 \mathrm{~mL}$ water sample [29]. However, some structural disadvantages associated with this group of phages also have to be stated. To study 
the structure of these phages there is a need to have accurate genetic information as their structure is labor-intensive. The capacity of the phage capsid naturally creates limitations for the amount of genetic material that can be presented in the phage genome. General ways to exhibit reporter genes contain recombination, transposition, direct cloning and homologous [8].

\subsection{Phage Display Peptides}

The phage display technology must be considered separately. Since, it was first reported in 1985 in Science, phage display technology has evolved as a powerful method for discovery of antigen-specific peptides. A researcher found that bacteriophages can be genetically manipulated through the incorporation of exogenous (poly) peptides into its coat proteins, making a peptides phage library. The filamentous phages, such as fd and M13, are the most commonly used vector to create random peptide display libraries. Filamentous phages appear as a flexible rod-shaped structure, with a total length of $880 \mathrm{~nm}$ and a diameter of $6.6 \mathrm{~nm}$. Its circular genome, of 6000-8000 bases, is enclosed in a coat composed of up of 2700 copies of major coat protein ( $\mathrm{pVIII}$ ), 3-5 copies each of the minor proteins (pIII, pVI and pVII, pIX), on the two ends of the phage particle. In particular, the foreign peptides (length from 6 to 21 amino acids) have been displayed fused to surface exposed N-terminus of all coat proteins. However, the most commonly-used coat proteins for phage display are pIII and pVIII. The phage display libraries consisted of up to $10^{10}$ different variants of phage particles with the linear random peptides [30]. This allows ligands to be screened that have a high affinity towards the desired antigen, such as eucariotic cells, bacteria or inorganic material. The phage clones were found to bind, with high affinity, the target, which can be used as a bio-probes in biosensor devises. In this way, for all possible targets, it is possible to find a "phage-clone" able to recognize them. The advantage are robust, stable and resistant to temperature variations and hard $\mathrm{pH}$ conditions, such as the wild-type. Moreover, the phage clone presents several copies of peptide of interest, thus increasing the avidity of the specific target binding, compared to the classic wild-type [31]. It has introduced several opportunities in various fields, including vaccine design, targeted drug delivery and antiviral studies [31]. These characteristics make phages an attractive choice as probes for developing biosensors in several fields [32,33].

\subsection{Phage Receptor Binding Proteins}

Recently bacteriophage receptor binding proteins (RBPs) have been developed into tools that make use of their high specificity [34]. RBPs offer several advantages compared to other elements for example antibodies, including ligand specificity, greater stability, and affinity even against carbohydrate epitopes [35]. The rapid detection of pathogens prevents disease progression and spread. RBPs are a practical technology for bacterial diagnosis.

The phage receptor proteins determine the phage-host characteristics and are also considered as suitable as biological agents. One of the advantages of the RBP is that, without lysis, the bacterial components of the bacterial cell proliferate through the agglutination and release of the DNA of the pathogen. RBP often has good resistance to environmental factors, such as temperature and pH [36]. Poshtiban and coworkers anchored the phage NCTC12673 presenting RBP protein Gp047 on magnetic beads. The modified seeds were used to extract Campylobacter from milk and chicken samples. In samples infected with $10^{2} \mathrm{CFU} / \mathrm{mL}$ of Campylobacter cells through RT-PCR, it was a prominent improvement measure of more than $80 \%$ in $3 \mathrm{~h}$. To confirm the specific adsorption of phage to Campylobacter, S. typhimurium was used as a negative control [37]. More effort is needed to reach commercial biosensors, given that the initial experimental results indicate that RBPs are capable of being used as diagnostic agents in diagnosing pathogens.

\section{Phage-Based Biosensors}

In recent years, biosensors have been developed as new diagnostic methods to minimize the limitations of common pathogen detection methods. In phage-based biosensors, bacteriophage is 
attached to the sensor surface, and consequently, it can detect the pathogen in the sample [38]. The main advantages of this method are sensitive, accuracy and reliably. Bacteriophage-based biosensors have been used for direct diagnosis of pathogens in fresh foods such as milk [19,39], and water [40] food matrices [41]. The Table 1 summarizes the advantages of biosensors in pathogenesis.

Table 1. Ideal properties incorporated for microbial biosensor.

\begin{tabular}{cc}
\hline Assay time & Near real-time response desired $(<1 \mathrm{~h}$ desirable $)$ \\
Assay protocol & No reagent addition needed \\
Operator & Should be automated and require minimal operator skills \\
Strain selectivity & Ability to distinguish an individual bacterial strain from other strains of the same species \\
Low detection limit & Ability to detect single bacteria in a reasonably small sample volume (from 1 to $100 \mathrm{~mL})$ \\
Species selectivity & Ability to distinguish individual bacterial species in the presence of other microorganisms or cell. \\
Compatible interface & Should be compatible with the transduction principle and resist nonspecific binding \\
Robustness & Both mechanical and chemical stability is required \\
Monitoring & Direct, without pre-enrichment \\
Viable cell count & Should discriminate between live and dead cells \\
\hline
\end{tabular}

\subsection{Phage-Based Optical Biosensors}

Optical-based bioassay systems are used for rapid diagnosis of pathogens in different experimental conditions, with high sensitivity and compatibility. Optical biosensors are used as more suitable diagnostic systems for the detection of pathogens. Detection in optical biosensors is based on the variations induced in the light properties, such as refractive index, wavelength and polarization [42]. Currently, BIACORE 3000 biosensor and SPREETA biosensor as commercial optical biosensors are used for the detection of foodborne pathogens. BIACORE 3000 biosensor is used for detecting L. monocytogenes, with sensitivity of $1 \times 10^{5}$ cells $/ \mathrm{mL}$ in milk. Salmonella enteritidis and E. coli O157:H7, and S. typhimurium and S. enteritidis, can be successfully detected by BIACORE 3000. and SPREETA biosensors, respectively [43]. Wavelengths-based biosensors enable real-time monitoring of biomolecular interactions by evaluating the kinetics and affinity of the interactions [42]. Planar optical waveguides contain an optically transparent guiding layer with a refractive index, which is higher than the substrate layers. The optical waveguide geometry provides an excellent surface for functionalization and pattering of different recognition elements, and enable the simultaneous detection of multiple analytes in a single waveguide transducer [44]. Optical techniques are separated into two major subclasses, fluorescence and label-free, based on their working platform. The most used technique for these biosensors is the measure of the changed fluorescence, in absorbance or luminescence, of the biosensor surface after analyte recognition. Furthermore, one of the advantages of the optical biosensor design of label-free biosensors is the detection of a specific and susceptible bacterial pathogens [45]. The most employed techniques for bacterial detection are fluorescence/phosphorescence spectrometry, surface Plasmon resonance (SPR), and bio/chemiluminescence.

\subsubsection{Surface Plasmon Resonance Sensors (SPR)}

For the first time in 1990, SPR was used to detect a spectrum of materials [46]. SPR biosensors are optical sensors that use special surface plasmon-polaritons-electromagnetic waves, to monitor the interactions between an analyte in solution and a recognition layer, such as recognize molecules and phages, immobilized on the SPR sensor surface. SPR biosensing, as a spectroscopic technique, enable the quantitative and real-time detection of the binding events without labeling the interacting molecules. The optical system is comprised of an optical surface, a light emitting diode (LED), a glass prism and a photodiode array. The molecular interactions at the surface cause changes in the refractive index, leading to changes in the SPR angle of the reflected light. The photodiode array detects SPR angle changes, and expresses the signals as a response unit (RU). RU is directly proportional to the total mass of the bound ligands. The chips in these sensors usually contains a gold surface functionalized with specific biorecognition elements by chemical bounds [47]. Advanced SPR biosensors have been designed to detect pathogens using a variety of bio-probes in diagnosis of pathogens such as antibodies [48,49], 
bacteriophages [50] and lectins [51]. Bacteriophages are designed as diagnostic probes for specific detection of pathogens at the SPR level. For example, Singh et al. used immobilized engineered tail spike proteins derived from the P22 bacteriophage onto gold surfaces using thiol-chemistry, in order to selective real-time analytical detection of Salmonella with the sensitivity of $10^{3} \mathrm{CFU} / \mathrm{mL}^{-1}$ [24]. This technique successfully detects E. coli O157:H7, methicillin-resistant S. aureus (MRSA) [52], S. aureus, E. coli K12 [13] and hepatitis B virus (HBV) [53]. Full-length recombinant Det7 phage tail proteins (Det7T) are recently used in novel SPR devise for detection of Salmonella enterica serovar typhimurium. Det7T is covalently immobilized on gold-coated surfaces by amine-coupling, and can specifically bind to S. typhimurium. Rapid detection ( $20 \mathrm{~min}$ ) of $5 \times 104^{-5} \mathrm{CFU} / \mathrm{mL}$ S. typhimurium in water and $10 \%$ apple juice was observed by this biosensor [54]. In Table 2 several microorganisms that have been detected using this technique are summarized. The Plasmon waveguide resonance (PWR) spectroscopy, as a relatively new biophysical method, has the structures, which can couple high sensitivity of the SPR sensors and the small resonance width of the dielectric WG sensors. The PWR consists a glass substrate, a thin metallic layer, and a dielectric layer on the top of the metallic layer. The metallic layer plays a very important role in exciting the dielectric waveguide modes (transverse magnetic (TM), and transverse electric (TE). As an example, optical metal clad leaky waveguide (MCLW) sensor can detect Bacillus subtilis var. niger using index changes, scattering and fluorescence from bacterial spores bond to immobilized antibody [55].

Table 2. Table based on phage-based biosensors in diagnosis of pathogens according to the type of phage, type of sample, duration of diagnosis and limit of detection achieved. Keys, NS, not stated.

\begin{tabular}{|c|c|c|c|c|c|c|}
\hline Transducer & Organism & $\begin{array}{l}\text { Bio-Probe } \\
\text { Phage }\end{array}$ & $\begin{array}{l}\text { Sample } \\
\text { Matrix }\end{array}$ & $\begin{array}{c}\text { Limit of } \\
\text { Detection } \\
(\mathrm{CFU} / \mathrm{mL})\end{array}$ & $\begin{array}{l}\text { Time Assay } \\
\text { (min) }\end{array}$ & Ref \\
\hline Optical biosensor & E. coli K12 & $\mathrm{T} 4$ & Skim milk & $7 \times 10^{2}$ & NS & {$[3,56]$} \\
\hline Optical biosensor & $\begin{array}{l}\text { E. coli } \\
\text { O157:H7 }\end{array}$ & $\mathrm{T} 4$ & Skim milk & $3 \times 10^{3}$ & NS & {$[52,56,57]$} \\
\hline Optical biosensor & MRSA & BP14 & - & $10^{3}$ & NS & [52] \\
\hline Optical biosensor & Salmonella & P22, TSP & $\begin{array}{c}\text { Chicken } \\
\text { carcass, wash }\end{array}$ & $4.4 \times 10^{4}$ & 3 & {$[24,58,59]$} \\
\hline Optical biosensor & C. jejuni & $\begin{array}{c}\text { NCTC } 12673 \\
\text { TSP }\end{array}$ & $\begin{array}{l}\text {-Contaminant } \\
\text { milk }\end{array}$ & $10^{2}$ & 45 & {$[60,61]$} \\
\hline Bioluminesence & E. coli & E. coli & - & $\begin{array}{c}\text { Fewer than } \\
10^{3}\end{array}$ & 60 & [62] \\
\hline Bioluminesence & $\begin{array}{l}\text { Salmonella } \\
\text { enteritidis }\end{array}$ & SJ2 & - & $10^{3}$ & 120 & [63] \\
\hline Fluorescent & E.coli O157:H7 & $\mathrm{T} 7$ & $\begin{array}{l}\text { Culture } \\
\text { medium, } \\
\text { water }\end{array}$ & $10^{7}$ & 10 & {$[40,64]$} \\
\hline QCM & $\begin{array}{l}\text { Salmonella } \\
\text { typhimurium }\end{array}$ & Filamentous & Chicken wash & $10^{2}$ & 60 & {$[65,66]$} \\
\hline Impedimetric & E. coli & $\mathrm{T} 4$ & - & $10^{4}$ & 30 & [61-63] \\
\hline
\end{tabular}

\subsubsection{Bioluminescence Sensors}

Bioluminescence through the oxidation of organic compounds (Luciferin), due to the enzyme Luciferase, produces visible light in the living organisms. Commonly in marine environments, some bacteria, including Vibrio strains, are widely and abundantly used as luminescent organisms. The ATP Bioluminescence tests are a sensitive, fast and simple ways for bacterial detection. In this method, the bacterial cell is lysed and releases intracellular ATP which is measured by luciferase bioluminescence reaction. The problem of this method is the low specificity in both Adenylate kinase (AK) and ATP diagnosis. Wu et al. showed that the rate of the release of AK from the bacterial cell depends on the growth stage, phage type infection time and type of bacteria [63]. 


\subsubsection{Fluorescent Bioassay}

In this way, the fluorescent combination with bacteriophage plays a role in the diagnosis of pathogens. In this method, fluorescent blended bacteriophages are involved in detecting and binding to the host bacteria. Phage-bacteria is discovered using flow cytometry or epifluorescent filter technique. The average sensitivity reported so far is around $10^{4} \mathrm{CFU} / \mathrm{mL}^{-1}$ for flow cytometric and around $10^{2}-10^{3}$ $\mathrm{CFU} / \mathrm{mL}^{-1}$ for epifluorescent microscopy detection $[67,68]$. Goodridge et al. combined this method with immunomagnetic separation. In this way they could be able to detect 10 to $10^{2} \mathrm{CFU} / \mathrm{mL}^{-1} \mathrm{E}$. coli O157: H7 in synthetic milk after an enrichment [39] phase for $10 \mathrm{~h}$ and $10^{4} \mathrm{CFU} / \mathrm{mL}^{-1}$ of E.coli O157:H7 in broth [69]. This method is also used to identify bacterial toxins [70]. Goldman et al. displayed a practical phage to select a 12-per peptide that could bind to staphylococcal enterotoxin B (SEB), which cause food toxication. They could detect low $1.4 \mathrm{ng}$ of SEB per sample in a fluorescence-based immunoassay using a labeled SEB-binding phage [70].

\subsection{Electrochemical Biosensors}

\subsubsection{Amperometric Biosensors}

Amperometric biosensors are based on measuring the flow generated by oxidation or reduction in response to analyte bio-receptor reactions. In this case, a bio-receptor is usually an enzyme, such as glucose oxidase, horseradish peroxidase (HRP) and alkaline phosphatase (AP) [71]. In general, this technology includes a thin plate of gold or platinum or carbon. The main advantage of these biosensors is that they are simple and easy to use, and at the same time, highly sensitive. The limitation of this method is low specificity due to interference with active inhibitors, and then the signal inaccuracies. In this method, a quantification of coliform E. coli K-12 with intermediary phages and intracellular release of bacterial enzymes, such as D-galactosidase and carbon oxides can be investigated [72]. This sensor detected $1 \mathrm{CFU} / 100 \mathrm{~mL}$ of bacteria from the sample, but need to pre-incubation phase. Neufeld et al. combined the phage typing technique with amperometric for the specific detection of Mycobacterium smegmatis, E. coli K12, and Bacillus cereus [72]. The basis of these sensors is that through phage infection, it causes bacterial leakage and the spread of intracellular bacterial content, including the enzyme. Enzymatic activity is measurable in a specific substrate. The recent advanced reports, nanoparticle transducers were used to reduce the limitation of electrochemical biosensors. The Gold nanoparticle is one of the most common nanoparticles used in MRI, biosensors and targeting drug delivery for treating brain diseases, significantly increased electrodes sensitivity to the detection of pathogens. Xu et al. designed micro-gold electrodes with phage T4 for the detection of E. coli. The sensitivity of this biosensor is in the range of $1.9 \times 10^{1}-1.9 \times 10^{8} \mathrm{CFU} / \mathrm{mL}$ bacteria [17]. Table 3 are summarized in several nanoparticles that have been used for detecting microorganisms.

Table 3. The nanoparticle phage-based biosensors in the diagnosis of pathogens according to type of phage, type of sample, duration of diagnosis and limit of detection.

\begin{tabular}{|c|c|c|c|c|c|}
\hline Immobilization Material & Biosensor & $\begin{array}{l}\text { Bio-Probe } \\
\text { Phage }\end{array}$ & Organism & $\begin{array}{l}\text { Limit of } \\
\text { Detection } \\
\text { (CFU/mL) }\end{array}$ & Ref \\
\hline Gold & Fluorescence & $\mathrm{T} 4$ & E. coli & ND & [73] \\
\hline $\begin{array}{l}\text { Nano-aluminium fiber } \\
\text { based filter }\end{array}$ & Bioluminescence & $\begin{array}{l}\text { Wild type and } \\
\text { modified T4 }\end{array}$ & E. coli & $6 \times 10^{3}$ & [74] \\
\hline Silica particle & $\begin{array}{l}\text { Bioluminescence } \\
\text { lux system }\end{array}$ & $\begin{array}{l}\text { Phage A1122 } \\
\text { with lux tag }\end{array}$ & Yersinia pestis & $10^{2}$ & [75] \\
\hline $\begin{array}{l}\text { Carbon solid-phase } \\
\text { extraction microarray }\end{array}$ & Impediametric & $\mathrm{T} 4$ & E. coli $\mathrm{K} 12$ & $10^{2}-10^{8}$ & [76] \\
\hline $\begin{array}{l}\text { Carbon solid-phase extraction } \\
\text { with magnetic beads }\end{array}$ & Impediametric & $\mathrm{T} 4$ & E. coli $\mathrm{K} 12$ & $10^{2}-10^{8}$ & [77] \\
\hline $\begin{array}{l}\text { Pencil graphit electrodes with } \\
\text { gold nano rods }\end{array}$ & Impediametric & $\mathrm{T} 4$ & E. coli $\mathrm{K} 12$ & $10^{2}-10^{6}$ & [78] \\
\hline
\end{tabular}




\subsubsection{Electrochemical Impedance Spectroscopy (EIS) Biosensors}

Electrochemical impedance spectroscopy (EIS) is a powerful technique in detecting the electrochemical system. Functional sinusoidal in the system measures the changes in the electrical impedance in the medium. The analysis is carried out based on changes in capacitance, conductance, and impedance. The capacity is often reduced due to the process of microbial metabolism and impedance decreases [79]. Here, bacteriophages are used as diagnostic probes to detect pathogens at the electrode surface. In a study, the impedance was reduced as bacterial concentration enhanced, which is contrary to normal attachment of entire cells on EIS, a promising electrochemical biosensor. Bacteria can be detected by capturing electrons on the electrode surface. In EIS electrochemical sensors with bacteriophage, as a probe, are used to detect bacteria, trough catching the bacteria target the immobilized phages on electrodes, functional groups $[17,80]$. The main cause of this is the activity of lytic phages on bacteria, which causes the intracellular content to drop out and decrease the conductivity. E. coli was easily detected in pure culture media or inoculated samples in a range between $10^{4}-10^{7} \mathrm{CFU}$ $\mathrm{mL}^{-1}$ using this method [81]. Webster et al. extend an impedimetric microelectrode array biosensor bacteriophage-based for the detection of bacteria. The results have shown that decreased the width and gap of an electrode and using the working solution with lower relative dielectric permittivity can enhance the sensitivity of impedimetric biosensors for pathogenic bacteria [82]. Graphene is wonder materials with superior properties and using graphene a screen-printed graphene electrode (SPE) for the detection of $S$. arlettae. Specific lytic phage against $S$. arlettae was immobilized on the sensor surface for quantitative analysis of the bacterial cells and capturing bacteria using EIS biosensor. Accordingly, the increase in the concentration of bacteria $\left(2-2 \times 10^{6} \mathrm{CFU} / \mathrm{mL}\right)$ leads to an increased quantity of charge transfer resistance $\left(R_{c t}\right)$. The limit of detection was defined as around $2 \mathrm{CFU} / \mathrm{mL}[83]$.

\section{Benefits and Challenges}

In these techniques, phages are widely used as bio-probes to detect pathogens. Phages are specific for host bacteria and have different characteristics, including that they are easy to amplify and cheap to produce, are resistant to temperature and $\mathrm{pH}$-degradation, as well as organic solvents [74-77]. Moreover, cloning of engineered phage, derived from phage display libraries, make it able to develop new phages with on demand binding unites on their surfaces. This makes the phages a very promising candidate for biosensor applications [13]. Optimization of phage size, expression of binding units on phage's surface for specific binding to bacteria, are of the main troubleshooting in development of new phage-based biosensors.

\section{Conclusions and Remarks}

Biosensors have already demonstrated huge potential in many fields, including detection of viruses and diseases in patients, as well as in the identification of food pathogens. Many of these devices are still at laboratories' experimental bases and translation to the commercial product has been slow. The main problem, includes a signal-to-noise ratio, caused by the separation of signals from bacteria, due to the unwanted signal "noise" from the samples. Therefore, sensitivity and repeatability are the major problems in the biosensors. High specificity is one of the main features of biosensors in diagnosis assisted by sensitivity, without spending time for the pre-enrichment phase.

Here, a summary of bacteriophage-based bio-probes and their protein receptors are discussed. At the same specificity of the antibodies and nucleic acid, the phage probes are strong, resistant and cost-effective. Recent efforts have led to advances in methods in which phage, based on its chemical properties, is positioned on the surface of the sensor and provides a consistent and stable surface that results in a widespread diagnosis. Although, phage-based and RBP-based systems have improved food quality control, it is still an emerging system. Significant advances have been made in this area and there is a clear and promising future.

Finally advances in cutting edge $\mathrm{R}$ and $\mathrm{D}$ on nanomaterials and smart materials, including recent work on graphene-based biosensors [84,85], will speed-up development and translate to 
commercialization. The current situation with Coronavirus is a warning to all on how important of fast and reliable detection of viruses in reducing mortality.

Author Contributions: Conceptualization, M.G., A.H. and A.S.; methodology, M.G. and A.H.; writing-original draft preparation, Z.A.A.; writing-review and editing, M.G., A.S., A.H. and L.M.D.P. All authors have read and agreed to the published version of the manuscript.

Funding: This research was funded by Shahid Beheshti University of Medical Sciences, grant number 13081" and Iran University of Medical Sciences, grant number 32827.

Conflicts of Interest: The authors declare that they have no competing interests.

\section{Abbreviations}

$\begin{array}{ll}\text { AK } & \text { adenylate kinase } \\ \text { ALP } & \text { alkaline phosphatase } \\ \text { CDC } & \text { centers for disease control and prevention } \\ \text { CFU } & \text { colony forming unit; ELISA, enzyme-linked immunosorbent assay } \\ \text { EIS } & \text { electrochemical impedance spectroscopy } \\ \text { HRP } & \text { horseradish peroxidase } \\ \text { LED } & \text { light emitting diode } \\ \text { MCLW } & \text { metal clad leaky waveguide } \\ \text { MRSA } & \text { methicillin-resistant staphylococcus aureus } \\ \text { Nluc } & \text { NanoLuc } \\ \text { PDPs } & \text { phage-display peptides } \\ \text { PCR } & \text { polymerase chain reaction } \\ \text { QCM } & \text { quartz crystal microbalance } \\ \text { RBPs } & \text { receptor binding proteins } \\ \text { R } & \text { resistance charge transfer } \\ \text { RT-PCR } & \text { reverse transcriptase PCR } \\ \text { RU } & \text { response unit } \\ \text { R\&D } & \text { research and development } \\ \text { SPR } & \text { surface plasmon resonance } \\ \text { SEB } & \text { staphylococcal enterotoxin B } \\ \text { SPE } & \text { screen-printed graphene electrode } \\ \text { TE } & \text { transverse electric } \\ \text { TM } & \text { transverse magnetic } \\ \text { VBNC } & \text { viable-but non-cultivable } \\ \text { WHO } & \text { World Health Organization } \\ & \end{array}$

\section{References}

1. Oliver, S.P.; Jayarao, B.M.; Almeida, R.A. Foodborne pathogens in milk and the dairy farm environment: Food safety and public health implications. Foodborne Pathog. Dis. 2005, 2, 115-129. [CrossRef] [PubMed]

2. Klevens, R.M.; Edwards, J.R.; Richards, C.L., Jr.; Horan, T.C.; Gaynes, R.P.; Pollock, D.A.; Cardo, D.M. Estimating health care-associated infections and deaths in US hospitals, 2002. Public Health Rep. 2007, 122, 160-166. [CrossRef] [PubMed]

3. Arya, S.K.; Singh, A.; Naidoo, R.; Wu, P.; McDermott, M.T.; Evoy, S. Chemically immobilized T4-bacteriophage for specific Escherichia coli detection using surface plasmon resonance. Analyst 2011, 136, 486-492. [CrossRef]

4. Tirado, M.; Clarke, R.; Jaykus, L.; McQuatters-Gollop, A.; Frank, J. Climate change and food safety: A review. Food Res. Int. 2010, 43, 1745-1765. [CrossRef]

5. Chung, M.S.; Kim, C.M.; Ha, S.D. Detection and enumeration of microorganisms in ready-to-eat foods, ready-to-cook foods and fresh-cut produce in Korea. J. Food Saf. 2010, 30, 480-489. [CrossRef]

6. Singh, A.; Poshtiban, S.; Evoy, S. Recent advances in bacteriophage based biosensors for food-borne pathogen detection. Sensors 2013, 13, 1763-1786. [CrossRef]

7. Mandal, P.; Biswas, A.; Choi, K.; Pal, U. Methods for rapid detection of foodborne pathogens: An overview. Am. J. Food Technol. 2011, 6, 87-102. [CrossRef] 
8. Zhao, X.; Lin, C.-W.; Wang, J.; Oh, D.H. Advances in rapid detection methods for foodborne pathogens. J. Microbiol. Biotechnol. 2014, 24, 297-312. [CrossRef]

9. Coburn, J.; Gill, D. ADP-ribosylation of p21ras and related proteins by Pseudomonas aeruginosa exoenzyme S. Infect. Immun. 1991, 59, 4259-4262. [CrossRef]

10. Ruzin, A.; Keeney, D.; Bradford, P.A. AdeABC multidrug efflux pump is associated with decreased susceptibility to tigecycline in Acinetobacter calcoaceticus-Acinetobacter baumannii complex. J. Antimicrob. Chemother. 2007, 59, 1001-1004. [CrossRef]

11. Bhalla, N.; Jolly, P.; Formisano, N.; Estrela, P. Introduction to biosensors. Essays Biochem. 2016, 60, 1-8. [PubMed]

12. Velusamy, V.; Arshak, K.; Korostynska, O.; Oliwa, K.; Adley, C. An overview of foodborne pathogen detection: In the perspective of biosensors. Biotechnol. Adv. 2010, 28, 232-254. [CrossRef] [PubMed]

13. Singh, A.; Arutyunov, D.; Szymanski, C.M.; Evoy, S. Bacteriophage based probes for pathogen detection. Analyst 2012, 137, 3405-3421. [CrossRef] [PubMed]

14. Doss, J.; Culbertson, K.; Hahn, D.; Camacho, J.; Barekzi, N. A review of phage therapy against bacterial pathogens of aquatic and terrestrial organisms. Viruses 2017, 9, 50. [CrossRef]

15. Alcaine, S.; Law, K.; Ho, S.; Kinchla, A.; Sela, D.; Nugen, S. Bioengineering bacteriophages to enhance the sensitivity of phage amplification-based paper fluidic detection of bacteria. Biosens. Bioelectron. 2016, 82, 14-19. [CrossRef]

16. Bárdy, P.; Pantůček, R.; Benešík, M.; Doškař, J. Genetically modified bacteriophages in applied microbiology. J. Appl. Microbiol. 2016, 121, 618-633. [CrossRef]

17. Xu, J.; Chau, Y.; Lee, Y.-k. Phage-based electrochemical sensors: A review. Micromachines 2019, 10, 855. [CrossRef]

18. Lakshmanan, R.S.; Guntupalli, R.; Hu, J.; Kim, D.-J.; Petrenko, V.A.; Barbaree, J.M.; Chin, B.A. Phage immobilized magnetoelastic sensor for the detection of Salmonella typhimurium. J. Microbiol. Methods 2007, 71, 55-60. [CrossRef]

19. Lakshmanan, R.S.; Guntupalli, R.; Hu, J.; Petrenko, V.A.; Barbaree, J.M.; Chin, B.A. Detection of Salmonella typhimurium in fat free milk using a phage immobilized magnetoelastic sensor. Sens. Actuators B Chem. 2007, 126, 544-550. [CrossRef]

20. Singh, A.; Glass, N.; Tolba, M.; Brovko, L.; Griffiths, M.; Evoy, S. Immobilization of bacteriophages on gold surfaces for the specific capture of pathogens. Biosens. Bioelectron. 2009, 24, 3645-3651. [CrossRef]

21. Gervais, L.; Gel, M.; Allain, B.; Tolba, M.; Brovko, L.; Zourob, M.; Mandeville, R.; Griffiths, M.; Evoy, S. Immobilization of biotinylated bacteriophages on biosensor surfaces. Sens. Actuators B Chem. 2007, 125, 615-621. [CrossRef]

22. Mortari, A.; Lorenzelli, L.; Nicolò, M.; Guglielmino, S.; De Plano, L.M. Progress toward the development of a lytic bacteriophages-based impedance microbiology for agro-food application. In Sensors; Springer: Cham, Switzerland, 2015; pp. 83-87.

23. Lindberg, A.; Wollin, R.; Gemski, P.; Wohlhieter, J. Interaction between bacteriophage Sf6 and Shigella flexner. J. Virol. 1978, 27, 38-44. [CrossRef] [PubMed]

24. Singh, A.; Arya, S.K.; Glass, N.; Hanifi-Moghaddam, P.; Naidoo, R.; Szymanski, C.M.; Tanha, J.; Evoy, S. Bacteriophage tailspike proteins as molecular probes for sensitive and selective bacterial detection. Biosens. Bioelectron. 2010, 26, 131-138. [CrossRef] [PubMed]

25. Wisuthiphaet, N.; Yang, X.; Young, G.M.; Nitin, N. Rapid detection of Escherichia coli in beverages using genetically engineered bacteriophage T7. AMB Express 2019, 9, 55. [CrossRef] [PubMed]

26. Jain, P.; Hartman, T.E.; Eisenberg, N.; O’Donnell, M.R.; Kriakov, J.; Govender, K.; Makume, M.; Thaler, D.S.; Hatfull, G.F.; Sturm, A.W. \$2GFP10: A high-intensity fluorophage enables detection and rapid drug susceptibility testing of Mycobacterium tuberculosis directly from sputum samples. J. Clin. Microbiol. 2012, 50, 1362-1369. [CrossRef]

27. Zhang, D.; Coronel-Aguilera, C.P.; Romero, P.L.; Perry, L.; Minocha, U.; Rosenfield, C.; Gehring, A.G.; Paoli, G.C.; Bhunia, A.K.; Applegate, B. The use of a novel NanoLuc-based reporter phage for the detection of Escherichia coli O157: H7. Sci. Rep. 2016, 6, 33235. [CrossRef]

28. Zink, R.; Loessner, M.J. Classification of virulent and temperate bacteriophages of Listeria spp. on the basis of morphology and protein analysis. Appl. Environ. Microbiol. 1992, 58, 296-302. [CrossRef] 
29. Hinkley, T.; Garing, S.; Singh, S.; Le Ny, A.M.; Nichols, K.; Peters, J.; Talbert, J.N.; Nugen, S. Reporter bacteriophage T7 NLC utilizes a novel NanoLuc: CBM fusion for the ultrasensitive detection of Escherichia coli in water. Analyst 2018, 143, 4074-4082. [CrossRef]

30. Guo, Y.; Liang, X.; Zhou, Y.; Zhang, Z.; Wei, H.; Men, D.; Luo, M.; Zhang, X.-E. Construction of bifunctional phage display for biological analysis and immunoassay. Anal. Biochem. 2010, 396, 155-157. [CrossRef] [PubMed]

31. Haq, I.U.; Chaudhry, W.N.; Akhtar, M.N.; Andleeb, S.; Qadri, I. Bacteriophages and their implications on future biotechnology: A review. Virol. J. 2012, 9, 9. [CrossRef] [PubMed]

32. De Plano, L.M.; Scibilia, S.; Rizzo, M.G.; Crea, S.; Franco, D.; Mezzasalma, A.M.; Guglielmino, S.P. One-step production of phage-silicon nanoparticles by PLAL as fluorescent nanoprobes for cell identification. Appl. Phys. A 2018, 124, 222. [CrossRef]

33. De Plano, L.M.; Fazio, E.; Rizzo, M.G.; Franco, D.; Carnazza, S.; Trusso, S.; Neri, F.; Guglielmino, S.P. Phage-based assay for rapid detection of bacterial pathogens in blood by Raman spectroscopy. J. Immunol. Methods 2019, 465, 45-52. [CrossRef] [PubMed]

34. Leiman, P.G.; Shneider, M.M. Contractile tail machines of bacteriophages. In Viral Molecular Machines; Springer: Cham, Switzerland, 2012; pp. 93-114.

35. Novotny, M.V.; Alley, W.R.; Mann, B.F. Analytical glycobiology at high sensitivity: Current approaches and directions. Glycoconj. J. 2013, 30, 89-117. [CrossRef] [PubMed]

36. Waseh, S.; Hanifi-Moghaddam, P.; Coleman, R.; Masotti, M.; Ryan, S.; Foss, M.; MacKenzie, R.; Henry, M.; Szymanski, C.M.; Tanha, J. Orally administered P22 phage tailspike protein reduces Salmonella colonization in chickens: Prospects of a novel therapy against bacterial infections. PLoS ONE 2010, 5, e13904. [CrossRef]

37. Poshtiban, S.; Javed, M.A.; Arutyunov, D.; Singh, A.; Banting, G.; Szymanski, C.M.; Evoy, S. Phage receptor binding protein-based magnetic enrichment method as an aid for real time PCR detection of foodborne bacteria. Analyst 2013, 138, 5619-5626. [CrossRef]

38. Casey, A.; Coffey, A.; McAuliffe, O. Genetics and genomics of bacteriophages: The evolution of bacteriophage genomes and genomic research. Bacteriophages Biol. Technol. Ther. 2017, 1-26.

39. Goodridge, L.; Chen, J.; Griffiths, M. The use of a fluorescent bacteriophage assay for detection of Escherichia coli O157: H7 in inoculated ground beef and raw milk. Int. J. Food Microbiol. 1999, 47, 43-50. [CrossRef]

40. Edgar, R.; McKinstry, M.; Hwang, J.; Oppenheim, A.B.; Fekete, R.A.; Giulian, G.; Merril, C.; Nagashima, K.; Adhya, $\mathrm{S}$. High-sensitivity bacterial detection using biotin-tagged phage and quantum-dot nanocomplexes. Proc. Natl. Acad. Sci. USA 2006, 103, 4841-4845. [CrossRef]

41. Anany, H.; Brovko, L.; El Dougdoug, N.K.; Sohar, J.; Fenn, H.; Alasiri, N.; Jabrane, T.; Mangin, P.; Ali, M.M.; Kannan, B. Print to detect: A rapid and ultrasensitive phage-based dipstick assay for foodborne pathogens. Anal. Bioanal. Chem. 2018, 410, 1217-1230. [CrossRef]

42. Huertas, C.S.; Calvo Lozano, O.; Mitchell, A.; Lechuga, L.M. Advanced evanescent-wave optical biosensors for the detection of nucleic acids: An analytic perspective. Front. Chem. 2019, 7, 724. [CrossRef]

43. Law, J.W.-F.; Ab Mutalib, N.-S.; Chan, K.-G.; Lee, L.-H. Rapid methods for the detection of foodborne bacterial pathogens: Principles, applications, advantages and limitations. Front. Microbiol. 2015, 5, 770. [CrossRef]

44. Mukundan, H.; Anderson, A.S.; Grace, W.K.; Grace, K.M.; Hartman, N.; Martinez, J.S.; Swanson, B.I. Waveguide-based biosensors for pathogen detection. Sensors 2009, 9, 5783-5809. [CrossRef]

45. Fan, X.; White, I.M.; Shopova, S.I.; Zhu, H.; Suter, J.D.; Sun, Y. Sensitive optical biosensors for unlabeled targets: A review. Anal. Chim. Acta 2008, 620, 8-26. [CrossRef] [PubMed]

46. Owen, V. Real-time optical immunosensors-A commercial reality. Biosens. Bioelectron. 1997, 12, i-ii. [CrossRef]

47. Vachali, P.P.; Li, B.; Bartschi, A.; Bernstein, P.S. Surface plasmon resonance (SPR)-based biosensor technology for the quantitative characterization of protein-carotenoid interactions. Arch. Biochem. Biophys. 2015, 572, 66-72. [CrossRef] [PubMed]

48. Wang, Y.; Knoll, W.; Dostalek, J. Bacterial pathogen surface plasmon resonance biosensor advanced by long range surface plasmons and magnetic nanoparticle assays. Anal. Chem. 2012, 84, 8345-8350. [CrossRef] [PubMed]

49. Baccar, H.; Mejri, M.; Hafaiedh, I.; Ktari, T.; Aouni, M.; Abdelghani, A. Surface plasmon resonance immunosensor for bacteria detection. Talanta 2010, 82, 810-814. [PubMed] 
50. Tripathi, S.M.; Bock, W.J.; Mikulic, P.; Chinnappan, R.; Ng, A.; Tolba, M.; Zourob, M. Long period grating based biosensor for the detection of Escherichia coli bacteria. Biosens. Bioelectron. 2012, 35, 308-312. [CrossRef]

51. Wang, Y.; Ye, Z.; Si, C.; Ying, Y. Monitoring of Escherichia coli O157: H7 in food samples using lectin based surface plasmon resonance biosensor. Food Chem. 2013, 136, 1303-1308. [CrossRef]

52. Tawil, N.; Sacher, E.; Mandeville, R.; Meunier, M. Surface plasmon resonance detection of E. coli and methicillin-resistant $S$. aureus using bacteriophages. Biosens. Bioelectron. 2012, 37, 24-29. [CrossRef]

53. Chuang, T.-L.; Wei, S.-C.; Lee, S.-Y.; Lin, C.-W. A polycarbonate based surface plasmon resonance sensing cartridge for high sensitivity HBV loop-mediated isothermal amplification. Biosens. Bioelectron. 2012, 32, 89-95. [CrossRef] [PubMed]

54. Hyeon, S.H.; Lim, W.K.; Shin, H.J. Novel surface plasmon resonance biosensor that uses full-length Det7 phage tail protein for rapid and selective detection of Salmonella enterica serovar Typhimurium. Biotechnol. Appl. Biochem. 2020. [CrossRef] [PubMed]

55. Zourob, M.; Mohr, S.; Treves Brown, B.J.; Fielden, P.R.; McDonnell, M.B.; Goddard, N.J. An integrated metal clad leaky waveguide sensor for detection of bacteria. Anal. Chem. 2005, 77, 232-242. [CrossRef] [PubMed]

56. Waswa, J.; Debroy, C.; Irudayaraj, J. Rapid detection of Salmonella enteritidis and Escherichia coli using surface plasmon resonance biosensor. J. Food Process Eng. 2006, 29, 373-385. [CrossRef]

57. Wang, L.; Shi, L.; Su, J.; Ye, Y.; Zhong, Q. Detection of Vibrio parahaemolyticus in food samples using in situ loop-mediated isothermal amplification method. Gene 2013, 515, 421-425. [CrossRef] [PubMed]

58. Taylor, A.D.; Ladd, J.; Yu, Q.; Chen, S.; Homola, J.; Jiang, S. Quantitative and simultaneous detection of four foodborne bacterial pathogens with a multi-channel SPR sensor. Biosens. Bioelectron. 2006, 22, 752-758. [CrossRef]

59. Lan, Y.-B.; Wang, S.-Z.; Yin, Y.-G.; Hoffmann, W.C.; Zheng, X.-Z. Using a surface plasmon resonance biosensor for rapid detection of Salmonella typhimurium in chicken carcass. J. Bion. Eng. 2008, 5, 239-246. [CrossRef]

60. Singh, A.; Arutyunov, D.; McDermott, M.T.; Szymanski, C.M.; Evoy, S. Specific detection of Campylobacter jejuni using the bacteriophage NCTC 12673 receptor binding protein as a probe. Analyst 2011, 136, 4780-4786. [CrossRef]

61. Wei, D.; Oyarzabal, O.A.; Huang, T.-S.; Balasubramanian, S.; Sista, S.; Simonian, A.L. Development of a surface plasmon resonance biosensor for the identification of Campylobacter jejuni. J. Microbiol. Methods 2007, 69, 78-85. [CrossRef]

62. Blasco, R.; Murphy, M.; Sanders, M.; Squirrell, D. Specific assays for bacteria using phage mediated release of adenylate kinase. J. Appl. Microbiol. 1998, 84, 661-666. [CrossRef]

63. Wu, Y.; Brovko, L.; Griffiths, M. Influence of phage population on the phage-mediated bioluminescent adenylate kinase (AK) assay for detection of bacteria. Lett. Appl. Microbiol. 2001, 33, 311-315. [CrossRef]

64. Radke, S.M.; Alocilja, E.C. A high density microelectrode array biosensor for detection of E. coli O157: H7. Biosens. Bioelectron. 2005, 20, 1662-1667. [CrossRef] [PubMed]

65. Olsen, E.V.; Sorokulova, I.B.; Petrenko, V.A.; Chen, I.-H.; Barbaree, J.M.; Vodyanoy, V.J. Affinity-selected filamentous bacteriophage as a probe for acoustic wave biodetectors of Salmonella typhimurium. Biosens. Bioelectron. 2006, 21, 1434-1442. [CrossRef] [PubMed]

66. Su, X.-L.; Li, Y. A QCM immunosensor for Salmonella detection with simultaneous measurements of resonant frequency and motional resistance. Biosens. Bioelectron. 2005, 21, 840-848. [CrossRef]

67. Lee, S.; Onuki, M.; Satoh, H.; Mino, T. Isolation, characterization of bacteriophages specific to Microlunatus phosphovorus and their application for rapid host detection. Lett. Appl. Microbiol. 2006, 42, 259-264. [CrossRef] [PubMed]

68. Hennes, K.P.; Suttle, C.A.; Chan, A.M. Fluorescently labeled virus probes show that natural virus populations can control the structure of marine microbial communities. Appl. Environ. Microbiol. 1995, 61, 3623-3627. [CrossRef]

69. Goodridge, L.; Chen, J.; Griffiths, M. Development and characterization of a fluorescent-bacteriophage assay for detection of Escherichia coli O157: H7. Appl. Environ. Microbiol. 1999, 65, 1397-1404. [CrossRef]

70. Goldman, E.R.; Pazirandeh, M.P.; Mauro, J.M.; King, K.D.; Frey, J.C.; Anderson, G.P. Phage-displayed peptides as biosensor reagents. J. Mol. Recognit. 2000, 13, 382-387. [CrossRef]

71. Wang, J. Glucose biosensors: 40 years of advances and challenges. Electroanal. Int. J. Devot. Fundam. Pract. Asp. Electroanal. 2001, 13, 983-988. [CrossRef] 
72. Neufeld, T.; Schwartz-Mittelmann, A.; Biran, D.; Ron, E.; Rishpon, J. Combined phage typing and amperometric detection of released enzymatic activity for the specific identification and quantification of bacteria. Anal. Chem. 2003, 75, 580-585. [CrossRef]

73. Kretzer, J.W.; Lehmann, R.; Schmelcher, M.; Banz, M.; Kim, K.-P.; Korn, C.; Loessner, M.J. Use of high-affinity cell wall-binding domains of bacteriophage endolysins for immobilization and separation of bacterial cells. Appl. Environ. Microbiol. 2007, 73, 1992-2000. [CrossRef] [PubMed]

74. Minikh, O.; Tolba, M.; Brovko, L.; Griffiths, M. Bacteriophage-based biosorbents coupled with bioluminescent ATP assay for rapid concentration and detection of Escherichia coli. J. Microbiol. Methods 2010, 82, 177-183. [CrossRef] [PubMed]

75. Schofield, D.A.; Molineux, I.J.; Westwater, C. Diagnostic bioluminescent phage for detection of Yersinia pestis. J. Clin. Microbiol. 2009, 47, 3887-3894. [CrossRef] [PubMed]

76. Shabani, A.; Zourob, M.; Allain, B.; Marquette, C.A.; Lawrence, M.F.; Mandeville, R. Bacteriophage-modified microarrays for the direct impedimetric detection of bacteria. Anal. Chem. 2008, 80, 9475-9482. [CrossRef]

77. Shabani, A.; Marquette, C.A.; Mandeville, R.; Lawrence, M.F. Magnetically-assisted impedimetric detection of bacteria using phage-modified carbon microarrays. Talanta 2013, 116, 1047-1053. [CrossRef]

78. Moghtader, F.; Congur, G.; Zareie, H.M.; Erdem, A.; Piskin, E. Impedimetric detection of pathogenic bacteria with bacteriophages using gold nanorod deposited graphite electrodes. RSC Adv. 2016, 6, 97832-97839. [CrossRef]

79. Ivnitski, D.; Abdel-Hamid, I.; Atanasov, P.; Wilkins, E.; Stricker, S. Application of electrochemical biosensors for detection of food pathogenic bacteria. Electroanal. Int. J. Devot. Fundam. Pract. Asp. Electroanal. 2000, 12, 317-325. [CrossRef]

80. Cinti, S.; Volpe, G.; Piermarini, S.; Delibato, E.; Palleschi, G. Electrochemical biosensors for rapid detection of foodborne Salmonella: A critical overview. Sensors 2017, 17, 1910. [CrossRef]

81. Pal, S.; Alocilja, E.C.; Downes, F.P. Nanowire labeled direct-charge transfer biosensor for detecting Bacillus species. Biosens. Bioelectron. 2007, 22, 2329-2336. [CrossRef]

82. Webster, M.; Timoshkin, I.; MacGregor, S.; Mattey, M. Computer aided modelling of an interdigitated microelectrode array impedance biosensor for the detection of bacteria. IEEE Trans. Dielectr. Electr. Insul. 2009, 16, 1356-1363. [CrossRef]

83. Bhardwaj, N.; Bhardwaj, S.K.; Mehta, J.; Mohanta, G.C.; Deep, A. Bacteriophage immobilized graphene electrodes for impedimetric sensing of bacteria (Staphylococcus arlettae). Anal. Biochem. 2016, 505, 18-25. [CrossRef] [PubMed]

84. Nezakati, T.; Seifalian, A.; Tan, A.; Seifalian, A.M. Conductive polymers: Opportunities and challenges in biomedical applications. Chem. Rev. 2018, 118, 6766-6843. [CrossRef] [PubMed]

85. Bobrinetskiy, I.I.; Knezevic, N.Z. Graphene-based biosensors for on-site detection of contaminants in food. Anal. Methods 2018, 10, 5061-5070. [CrossRef]

(C) 2020 by the authors. Licensee MDPI, Basel, Switzerland. This article is an open access article distributed under the terms and conditions of the Creative Commons Attribution (CC BY) license (http://creativecommons.org/licenses/by/4.0/). 